Proceedings of the International Congress on Advances in Applied Physics and Materials Science, Antalya 2011

\title{
Study of Ultrasonically Sprayed ZnO Films: Thermal Annealing Effect
}

\author{
F. Ozutok, B. Demirselcuk, E. Sarica, S. Turkyilmaz and V. Bilgin \\ Physics Department, University of Canakkale Onsekiz Mart, 17020, Canakkale, Turkey
}

\begin{abstract}
$\mathrm{ZnO}$ thin films were deposited on microscope glass substrates by ultrasonic spray pyrolysis technique. The effects of annealing under various temperatures on the optical and structural properties of $\mathrm{ZnO}$ thin films were analyzed. The as-deposited and annealed $\mathrm{ZnO}$ thin films were investigated by UV/VIS spectrophotometer and $\mathrm{X}$-ray diffractometer. Some of the optical properties of the films such as transmittance, absorbance and band gap energy were investigated by UV/VIS spectrophotometer. The crystallinity levels of the films were investigated, the structural parameters such as diffraction angle, full-width at half maximum, lattice parameters, grain size and dislocation density were calculated and structural properties were analyzed. X-ray diffraction patterns indicated that the $\mathrm{ZnO}$ films had a polycrystalline hexagonal wurtzite structure.
\end{abstract}

PACS: 78.20.Ci, 61.05.cp

\section{Introduction}

Zinc oxide $(\mathrm{ZnO})$ has attracted much attention recently for potential applications because of its wide band gap of $3.37 \mathrm{eV}$ and large exciton binding energy of $60 \mathrm{meV}$ at room temperature $[1,2] . \mathrm{ZnO}$ is one of the typical II-VI semiconductor materials having various optoelectronic device applications such as blue light-emitting diodes, electroluminescent devices, electrooptic modulators and window layers in photovoltaic cells and gas sensors $[3-5]$.

In this work, $\mathrm{ZnO}$ thin films have been prepared by ultrasonic spray pyrolysis technique using zinc acetate solution as precursor. The influence of thermal annealing on the structural and optical properties of the $\mathrm{ZnO}$ thin films is presented.

\section{Experimental}

The $\mathrm{ZnO}$ thin films were deposited with an ultrasonic spray pyrolysis (USP) system at a substrate temperature of $375^{\circ} \mathrm{C}$. The $\mathrm{Zn}\left(\mathrm{CH}_{3} \mathrm{COO}\right)_{2} \cdot 2 \mathrm{H}_{2} \mathrm{O}(0.1 \mathrm{M})$ solution has been prepared and sprayed onto microscope glass substrates following conditions: 1 - the solution was sprayed through an ultrasonic nozzle with air as the carrier gas at a pressure of $1 \mathrm{bar} ; 2$ - the ultrasonic frequency was $100 \mathrm{kHz}$, and the droplet size was $20 \mu \mathrm{m} ; 3$ - the total solution $(150 \mathrm{ml})$ was sprayed during $30 \mathrm{~min}$, and the solution flow rate controlled by a flowmeter was kept at $5 \mathrm{ml} \min ^{-1} ; 4$ - the distance between the nozzle and the substrate was maintained at $35 \mathrm{~cm} ; 5$ - the substrate temperature was controlled within $\pm 5^{\circ} \mathrm{C}$ with an iron-constantan thermocouple; 6 - after deposition process, films were annealed in air ambient at different temperatures of 200,300 and $400^{\circ} \mathrm{C}$ for $1 \mathrm{~h}$.

To investigate the crystalline structure of the films, Rigaku X-ray diffractometer (XRD) using $\mathrm{Cu} K_{\alpha}$ radiation $(\lambda=1.54059 \AA)$ was employed. The accelerating voltage of $40 \mathrm{kV}$, emission current of $30 \mathrm{~mA}$, and scanning speed of $2^{\circ} / \mathrm{min}$ were used. A range of $2 \theta$ from $20^{\circ}$ to $80^{\circ}$ was scanned, so that all possible diffraction peaks could be detected. The transmittance and absorbance spectra for all the films were recorded by a Shimadzu UV-2550 (double beam, 190-900 nm) spectrophotometer. The thicknesses of the films were measured by Filmetrics F20 thin film thickness measurement system and listed in Table I.

TABLE I

The thickness of the $\mathrm{ZnO}$ thin films as-grown and thermally annealed.

\begin{tabular}{c|c|c}
\hline \hline Material & $\begin{array}{c}\text { Annealing } \\
\text { temperature }\left[{ }^{\circ} \mathrm{C}\right]\end{array}$ & $\begin{array}{c}\text { Thickness } \\
{[\mathrm{nm}]}\end{array}$ \\
\hline \multirow{3}{*}{$\mathrm{ZnO}$} & as-grown & 247 \\
& 200 & 331 \\
& 300 & 340 \\
& 400 & 300
\end{tabular}

\section{Results and discussion}

\subsection{Structural analysis}

Figure 1 shows the XRD spectra of $\mathrm{ZnO}$ thin films as-grown and annealed at different temperatures. From these spectra, it was seen that all films have a polycrystalline structure of hexagonal form, with a (002) and (101) preferred orientations and important effect of annealing temperature on the preferential orientation of the films was observed. Also, annealing temperature has a strong effect on the intensities of the diffraction peaks.

For all films, the grain size $(D)$ was evaluated from the full width at half maximum (FWHM) for both (002) and (101) orientations by using the Scherrer equation [6], assuming a homogeneous strain across the films, and these values are given in Table II. It can be clearly seen that 


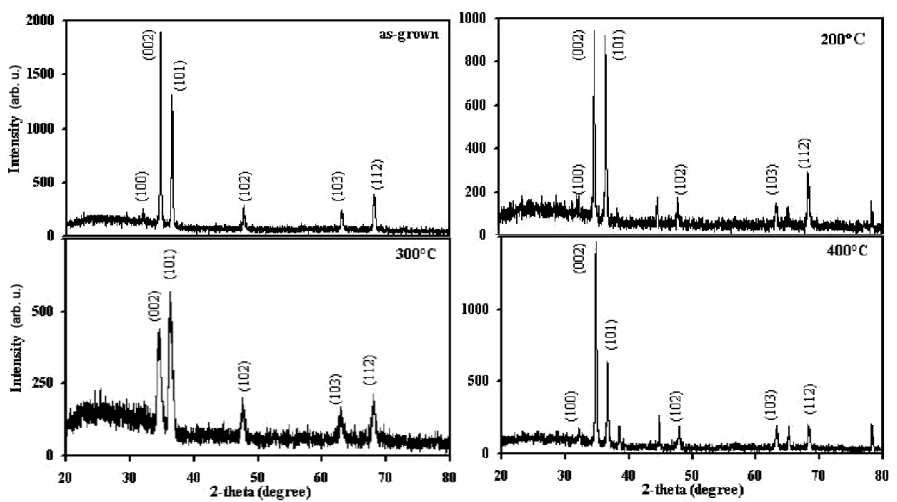

Fig. 1. XRD patterns for the $\mathrm{ZnO}$ thin films annealed at different temperatures. the grain size of the as-grown $\mathrm{ZnO}$ films decreased from 422 to $148 \AA$ [for (002) orientation] and 425 to $342 \AA$ [for (101) orientation] for $\mathrm{ZnO}$ films annealed at $300^{\circ} \mathrm{C}$ showing the deterioration in the crystallinity of the films. Similar decrease on grain size was seen for other annealed films.

Additionally, the dislocation density $(\delta)$, listed in Table II and defined as the length of dislocation lines per unit volume of the crystal, was calculated from the $\delta=1 /(D)^{2}$ formula [7], where $D$ is the grain size. The crystallization levels of the films annealed at $300^{\circ} \mathrm{C}$ are worse because of their high $\delta$ values which represent the amount of defects in the film. Larger $D$ and smaller $\delta$ values indicate better crystallization of the material. This means that thermal annealing process increases the defects in the as-grown $\mathrm{ZnO}$ films and deteriorates crystallite quality.

TABLE II

The angle of diffraction $(2 \theta)$, interplanar distance $(d)$, the grain size $(D)$ and the dislocation density $(\delta)$ of the $\mathrm{ZnO}$ thin films.

\begin{tabular}{c|c|c|c|c|c|c|c|c}
\hline \hline \multirow{2}{*}{ Material } & \multicolumn{2}{|c|}{$2 \theta$} & \multicolumn{2}{c|}{$d[\AA]$} & \multicolumn{2}{c|}{$D[\AA]$} & \multicolumn{2}{c}{$\delta[\AA]^{-2} \times 10^{-6}$} \\
\cline { 2 - 9 } & $(002)$ & $(101)$ & $(002)$ & $(101)$ & $(002)$ & $(101)$ & $(002)$ & $(101)$ \\
\hline $\mathrm{ZnO}$ (as-grown) & 34.64 & 36.44 & 2.587 & 2.464 & 422 & 425 & 5.62 & 5.54 \\
$\mathrm{ZnO}$ (annealed at $\left.200^{\circ} \mathrm{C}\right)$ & 34.84 & 36.60 & 2.573 & 2.453 & 371 & 381 & 7.27 & 6.89 \\
$\mathrm{ZnO}$ (annealed at $\left.300^{\circ} \mathrm{C}\right)$ & 34.80 & 36.54 & 2.576 & 2.457 & 148 & 342 & 45.7 & 8.55 \\
$\mathrm{ZnO}$ (annealed at $\left.400^{\circ} \mathrm{C}\right)$ & 34.82 & 36.62 & 2.575 & 2.452 & 368 & 371 & 7.38 & 7.27
\end{tabular}

TABLE III

The volume of the unit cell $(V)$ and the lattice parameters $(a, b$, and $c)$ of the $\mathrm{ZnO}$ thin films.

\begin{tabular}{l|c|c|c|c|c|c}
\hline \hline \multirow{2}{*}{ Material } & \multicolumn{3}{|c|}{ Calculated } & \multicolumn{3}{c}{ ASTM card [9] } \\
\cline { 2 - 7 } & $V[\AA]^{3}$ & $a=b[\AA]$ & $c[\AA]$ & $V[\AA]^{3}$ & $a=b[\AA]$ & $c[\AA]$ \\
\hline $\mathrm{ZnO}$ (as-grown) & 46.89 & 3.2347 & 5.1748 & & & \\
$\mathrm{ZnO}$ (annealed at $\left.200^{\circ} \mathrm{C}\right)$ & 46.27 & 3.2221 & 5.1460 & \multirow{2}{*}{47.6} & 3.250 & 5.207 \\
$\mathrm{ZnO}$ (annealed at $\left.300^{\circ} \mathrm{C}\right)$ & 46.49 & 3.2282 & 5.1516 & & & \\
$\mathrm{ZnO}$ (annealed at $400^{\circ} \mathrm{C}$ ) & 46.23 & 3.2197 & 5.1490 & & &
\end{tabular}

In order to investigate variation of lattice parameters of the $\mathrm{ZnO}$ films with thermal annealing temperature, the volume of the unit cell $(V)$ and the lattice parameters $(a, b$, and $c)$ of the hexagonal $\mathrm{ZnO}$ were calculated according to the relations [8]:

$$
\frac{1}{d^{2}}=\frac{4}{3} \frac{h^{2}+h k+k^{2}}{a^{2}}+\frac{l^{2}}{c^{2}} \text { and } \quad V=\frac{\sqrt{3}}{2} a^{2} c .
$$

It is concluded that these values given in Table III almost agree with those obtained from the ASTM card for polycrystalline $\mathrm{ZnO}$ powder of hexagonal structure [9]. As seen from Table IV, the lattice constant $(c)$ value of the $\mathrm{ZnO}$ films slightly decreases with the annealing temperature.
TABLE IV

Band gap energies $\left(E_{\mathrm{g}}\right)$ and Urbach parameters $\left(E_{0}\right)$ for $\mathrm{ZnO}$ thin films.

\begin{tabular}{l|c|c}
\hline \hline Material & $E_{\mathrm{g}}[\mathrm{eV}]$ & $E_{0}[\mathrm{meV}]$ \\
\hline $\mathrm{ZnO}$ (as-grown) & 3.24 & 103 \\
$\mathrm{ZnO}$ (annealed at $\left.200^{\circ} \mathrm{C}\right)$ & 3.26 & 84 \\
$\mathrm{ZnO}\left(\right.$ annealed at $\left.300^{\circ} \mathrm{C}\right)$ & 3.27 & 81 \\
$\mathrm{ZnO}\left(\right.$ annealed at $\left.400^{\circ} \mathrm{C}\right)$ & 3.25 & 98
\end{tabular}




\subsection{Optical analysis}

The optical absorbance and transmittance spectra of all films are presented in Fig. 2. The average optical transmittance in the wavelength region (from 500 to $900 \mathrm{~nm}$ ) of $\mathrm{ZnO}$ thin films before thermal annealing is $43.8 \%$, while after annealed at $200{ }^{\circ} \mathrm{C}, 300^{\circ} \mathrm{C}$ and $400{ }^{\circ} \mathrm{C}$, the transmittance is $53.2 \%, 64.4 \%$, and $45.8 \%$, respectively. The transmittance is obviously increased with the thermal annealing, especially for films annealed at temperatures of $200{ }^{\circ} \mathrm{C}$ and $300^{\circ} \mathrm{C}$.
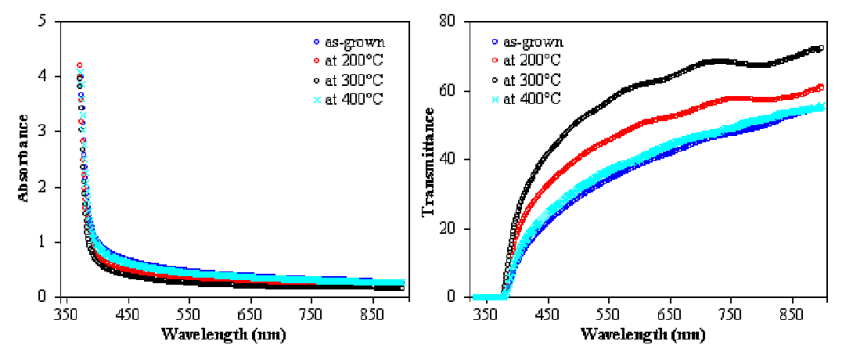

Fig. 2. Absorbance and transmittance spectra for the $\mathrm{ZnO}$ thin films.

In order to determine the band gap energy $E_{\mathrm{g}}$, the absorption coefficient data were analyzed. The relationship between the absorption coefficient $\alpha$ and the photon energy $h v$ for direct transition is given by [10]:

$$
\alpha h v \sim\left(h v-E_{\mathrm{g}}\right)^{1 / 2} .
$$

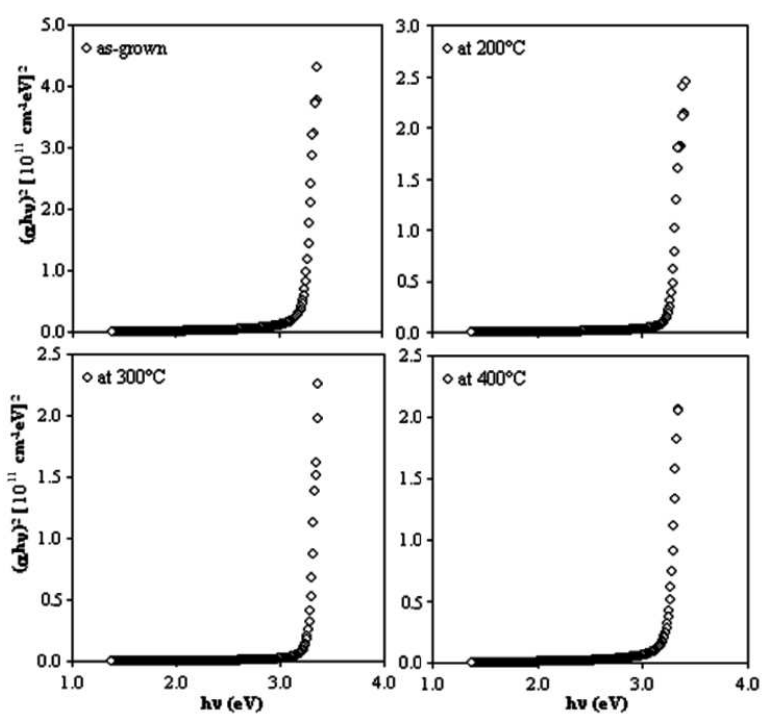

Fig. 3. The $(\alpha h v)^{2}$ versus photon energy $(h v)$ for the $\mathrm{ZnO}$ thin films.

The plots of $(\alpha h v)^{2}$ as a function of the photon energy $h v$ for all films are shown in Fig. 3. The optical band gap energy $E_{\mathrm{g}}$ could be obtained through extrapolating the linear portion of the curve to $(\alpha h v)^{2}=0$. The estimated band gap energy values are listed in Table IV. The optical band gap of the as-grown $\mathrm{ZnO}$ films slightly increases with the thermal annealing, but this increase is not considered as important. It is known that band gap energy of $\mathrm{ZnO}$ is sensitive to small changes in structural effects such as grain boundary configuration and film stress.

Generally, the absorption coefficient $\alpha(h v)$ in the low energy range follows the well-known exponential law, which is given by the Pankove expression [11]:

$$
\alpha(h v)=\alpha_{0} \exp \left(h v / E_{0}\right) \text { for } h v<E_{\mathrm{g}},
$$

where $\alpha_{0}$ is a constant, and $E_{0}$ is an Urbach parameter, having dimensions of energy and describing the width of the localized states in the band gap. From the slopes of the linear relationship between $\ln \alpha$ and $h v$ in the tail region, the Urbach parameters $E_{0}$ for the all films were estimated, and these results are given in Table IV.

\section{Acknowledgments}

This work was supported by the Canakkale Onsekiz Mart University Scientific Research Projects Committee under the project number 2010/199.

\section{References}

[1] D.C. Look, D.C. Reynolds, C.W. Litton, R.L. Jones, D.B. Eason, G. Cantwell, Appl. Phys. Lett. 81, 1830 (2002).

[2] Y. Natsume, H. Sakata, Thin Solid Films 372, 30 (2000).

[3] L. Liao, H.B. Lu, M. Shuai, J.C. Li, Y.L. Liu, C. Liu, Z.X. Shen, T. Yu, Nanotechnology 19, 175501 (2008).

[4] T. Makino, Y. Segawa, H. Koinuma, M. Kawasaki, Appl. Phys. Lett. 77, 1632 (2000).

[5] K. Toooka, Thin Solid Films 445, 37 (2003).

[6] H.H. Afify, R.S. Momtaz, W.A. Badawy, S.A. Nasser, J. Mater. Electron. 2, 40 (1991).

[7] Z. Zhao, D.L. Morel, C.S. Ferekides, Thin Solid Films 413, 203 (2002).

[8] B.D. Cullity, The Elements of X-ray Diffraction, 2nd ed., Addison-Wesley, Reading, MA 1956.

[9] Powder Diffraction File, Joint Committee on Powder Diffraction Standards, ASTM, Philadelphia, PA, 1967, Card 0361451 (for $\mathrm{ZnO}$ hexagonal) and 40831 (for Zn hexagonal).

[10] J. Tauc, R. Grigorovich, A. Vancu, Phys. Status Solidi 15, 627 (1966).

[11] J.I. Pankove, Optical Process in Semiconductors, Solid State Physical Electronics Series, Prentice-Hall, NJ 1971, p. 422. 